\title{
Projekt OpenStreetMap z pohledu geoinformatika
}

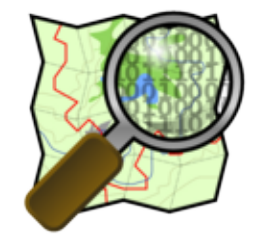 \\ Daniel Bárta \\ Institute of Geoinformatics, VSB-TU of Ostrava \\ daniel.barta.st2@vsb.cz
}

Keywords: OpenStreetMap, open geodata

Klíčová slova: OpenStreetMap, otevřená geodata

\begin{abstract}
This thesis discusses conditions suitable for creation of open-licensed geographic data, distinguishes different levels of opennes. It focuses the OpenStreetMap community project, which has the aim to create and provide free geographic data. This paper gives a brief insight to the project, presents its key features and its history.
\end{abstract}

\begin{abstract}
Abstrakt
Práce pojednává o podmínkách vhodných pro vytvár̆ení geodat se svobodnou licencí, rozlišuje rüznou úroveñ jejich otevrenosti. Dále se zaměruje na komunitni projekt OpenStreetMap, který vytvář́ a udržuje svobodná geografická data. Poskytuje prvotní náhled na projekt, seznamuje s jeho klíčovými vlastnostmi a vývojem.
\end{abstract}

\section{Od open source k open geodata}

Koncem 80. let 20. století začala vznikat, snad nejprve mezi programátory, potřeba vytvářet svobodné/otevřené programové vybavení. Snahy jednotlivců o vytvoření vhodných licencí pro publikování programů, propagace a případně hájení práv autorů a uživatelů byly později spojeny pod hlavičkou nadace Free Software Foundation GNU, nebo neziskové organizace Open Source Initiative. S odstupem času můžeme říci, že mnohé projekty vzešlé z této myšlenky 
hrají významnou roli v mnoha odvětvích informačních technologií - nápad několika nadšenců se změnil ve fenomén. Pro př́klad uved’me jádro operačního systému GNU/Linux, který je šířen pod často užívanou licencí GNU GPL, která je dnes ve třetí verzi. Klíčovým prvkem všeobecného rozšiřrení otevřeného softwaru byl přesun hardwarového vybavení ze sálů výpočetních středisek na každý pracovní stůl v zaměstnání či domovech.

Obdobným procesem prošel i hardware geoinformatiky a př́buzných oborů. V devadesátých letech 20. století byl uveden do provozu a zpř́stupněn veřejnosti projekt americké armády Navstar GPS [1]. Přijímače družicového signálu se z ponorek a amerických letadlových lodí postupně dostávají do každého motorového vozidla, do rukou turisty. Prvotní potřeba běžných uživatelů byla zjištování polohy a navigace, později přibyla i zábava jako např́íklad geocaching. Není tedy žádný důvod proč by obdobný proces jako bylo osvobození programového kódu nemohl začít v oblasti geoinformatiky a také, což je i tématem této práce, osvobození geodat.

\section{Otevřenost geodat}

Free Software Foundation popisuje možnost nahlížet na počítačové programy skrze míru svobody, s jakou lze s nimi pracovat.[2] Analogií tohoto přístupu, použitou na geodata, pak můžeme uvažovat:

\section{I. svoboda}

\section{Možnost zobrazit data (metadata), za jakýmkoliv účelem.}

Těchto možností je dnes mnoho, jak prostřednictvím produktů komerčních subjektů, tak státních organizací. Pro zobrazování dat využívají bud' účelově sestavený nebo standardizovaný mapserver. Využití dat je díky licenci možné pouze pro zobrazení a osobní potřebu, informace o metadatech jsou $\mathrm{k}$ dispozici jen z mlhavých dedukcí uživatelů. Nejjednodušší způsob provedení rozhraní mapserveru jsou v běžném internetovém prohlížeči zobrazitelné webové stránky na technologiích HTML, Javascript, AJAX. Jsou přístupné zpravidla veřejně a bez registrace, bývají přizpůsobené pro uživatele avšak nemají rozhraní vhodné a standardizované pro strojové zpracování.

České komerční mapové servery obsahují obvykle družicové nebo letecké snímky, automapu, uliční mapy měst, turistické mapy nebo trasy, př́ípadně staré mapy z 19. století. Jsou začasto omezené územím Česka, případně nejbližších sousedů. Příkladem může být:

- http://amapy.atlas.cz

- http://mapy.seznam.cz

- http://supermapy.centrum.cz

Zahraniční mapservery obsahující relevantní data k území České republiky jsou typické s nižší kvalitou a stářím geodat, nebot jejich původci jsou cizí organizace, mající těžiště zájmu mimo ČR. Poskytovány jsou zejména družicové nebo letecké snímky, automapy a uliční mapy měst. Např́klad:

- http://maps.google.com 
- http://maps.yahoo.com

- http://maps.live.com

Výjimečně se na českém Internetu objevují netypické služby, zpřístupňující dílčí části státního mapového díla jako např́klad:

- vizualizace UIR-ADR na RZM10 od MPSV ${ }^{1}$

Pokročilejší způsob výměny vizualizovaných geodat poskytuje služba standardu WMS provozovaná obvykle spolu s mapserverem, kterou lze snadno dále využívat v programovém vybavení nebo automatizovaně zpracovávat. Např́klad[14]:

- WMS CENIA ${ }^{2}$ (neposkytuje korektní výstup pro EPSG:4326)

- WMS Oblastní plán rozvoje lesa ÚHUL ${ }^{3}$

- WMS Katastrální mapa ČÚZK ${ }^{4}$

\section{II. svoboda}

Možnost studovat data a metadata a adaptovat je ke svým potřebám. Předpokladem je př́istup k zdrojovým datům.

Zde už je možností výrazně méně. Mưžeme sáhnout po ucelených komerčních sadách subjektů (ČÚZK viz tabulka, Arcdata, T-Mapy, ...). U těchto datasetů je však licence obvykle limitována - tedy k dispozici je sice forma zdrojových dat, ale způsob využijí je podstatně omezen.

\begin{tabular}{|l|l|}
\hline Název balíku dat & Cena za území ĆR \\
\hline Zabaged polohopis & $3.700 .000 \mathrm{Kč}$ \\
\hline Zabaged výškopis & $1.000 .000 \mathrm{Kč}$ \\
\hline Ortofotomapa CR $(0,5 \mathrm{~m} / \mathrm{px})$ & $2.400 .000 \mathrm{Kč}$ \\
\hline
\end{tabular}

Ukázka ceny dat, ceníku ČÚZK platný od 1. 1. 2007, převzato z [3]

Pro některá data rastrového datového modelu (např. letecké snímkování ve viditelném spektru) lze poskytnout zdrojová data skrze WMS službu. Vhodný zpo̊sob poskytování zdrojových dat vektorového datového modelu je WFS služba. Jedny z mála WMS/WFS služeb provozuje ÚHUL:

- WFS ÚHUL - lesní pokryv ČR ${ }^{5}$ (aktuálně nedostupné)

- WMS ÚHUL - panchromatické letecké snímky ČR, zdroj dat ČÚZK ${ }^{6}$

\section{III. svoboda}

\footnotetext{
${ }^{1}$ http://mapy.mpsv.cz:8080/mapy2/mpsv2.html

${ }^{2}$ http://geoportal.cenia.cz/

${ }^{3}$ http://geoportal2 . uhul.cz/cgi-bin/oprl . asp?service=WMS

${ }^{4}$ http: //wms. cuzk.cz/wms.asp

${ }^{5}$ http://212.158.143.149/cgi-bin/wfs?service=WFS

${ }^{6}$ http: //geoportal2 . uhul .cz/cgi-bin/oprl . asp? service=WMS
} 


\section{Možnost vytvářet kopie a volně je distribuovat.}

Pro typický př́klad se musíme poohlédnou do USA, kde je na data vytvořená státními organizacemi uplatňována nejčastěji licence public domain, tedy poskytování dat zdarma avšak bez záruky:

- vektorová data: NIMA (VMap0, VMap1), US CENSUS (Tiger)

- rastrová data: NASA (DEM, Landsat 7, SRTM) Mají celosvětové pokrytí v měřítkách do 1:1 000000 nebo podrobnější pro vybraná území zájmu USA (USA, Mexiko, část bývalého SSSR).

V České republice lze taktéž uvažovat o volně dostupných datových sadách s možností redistribuce, nicméně u nich neexistuje formálně definovaná licence, byt̉ např́íklad gestor MPSV, nebo ŘSD volné nakládání s daty neformálně předpokládá nebo připouští, naopak např. HEIS VUUV se staví proti. Obecně je postoj organizací a jednotlivců k poskytování vlastních dat třetím stranám ve znamení neochoty a nejistoty v definování vlastní licence. V případě souhlasu se jedná právně neformulovaný ústní nebo do e-mailu verbalizovaný souhlas. A to i v případě, kdy vznikají z veřejných prostředků a jsou ve zdrojovém formátu veřejně dostupné nebo výsledek volnočasové aktivity jedinců.[14][15] Na Českém území se jedná např́ḱlad o datasety:

- registry:

- UIR-ADR ${ }^{7}$ gestora MPSV

- UIR-ZSJ ${ }^{8}$ gestora ČSÚ

- vektorová data:

- generalizovaná komunikační sít ${ }^{9}$ Silniční databanky Ostrava správce ŘSD

- vodní toky ${ }^{10}$ Povodí Labe.

Možnost data upravovat, odvozovat jiná a tyto změny veřejně sdílet. Předpokladem je př́istup k zdrojovým datům.

Existují licence, které definici splňují nebo vynucují, avšak datové sady šířené pod touto licencí v Česku nejsou známy vyjma OpenStreetMap.

\section{Předpoklady pro vznik open-geodata projektu}

Vznik projektu zaměření na vytváření původních open-geodat (případně OpenStreetMap a obdobných) je obvykle motivován:

- Absentujícími geodaty, případně existující geodata nejsou dostupná veřejně a za dostatečně volných podmínek.

- Lidskou potřebou tvořit a vytvářet hodnoty i mimo činnost finančně honorovanou.

\footnotetext{
${ }^{7}$ http://forms.mpsv.cz/uir/

${ }^{8}$ http://www.czso.cz/csu/rso.nsf/i/prohlizec_uir_zsj

${ }^{9}$ http://www.rsd.cz/rsd/rsd.nsf/0/DFFC2FF000FC1FB3C1256DBF002CCEE3

${ }^{10}$ http: //www . pla.cz/planet/ram.aspx?id=21
} 
- Potřebou sdílet své znalosti a výsledky bez restrikcí a poskytovat je komunitě.

a předpokládá:

- svobodu pohybu

- volný čas (po práci, po škole)

- levný a dostupný hardware

- přístup ke službám (GPS, Internet)

Za těchto okolností může vzniknout komunitní projekt. OpenStreetMap (OSM) není samozřejmě první projekt zaměřený na vytváření/soustředění geodat. Nejčastěji ho předcházely mapy vytvářené uživateli přijímačů/navigátorů GPS Garmin. Později v západní Evropě vznikají lokální mapy na podobném principu jako OSM, účelové mapy např. pro projekt Wikipedia, speciální nebo lokální mapy, nebo vytvořením jednotného balíku datasetů třetích stran FreeGeodataCZ ${ }^{11}$. OSM je ale výjimečný svou životaschopností, přizpůsobivostí a lidským potenciálem. Zabývá se sběrem dat komplexně, nezávisle na cílovém mapovém výstupu a upotřebení, přesto však buduje rozhraní pro snadný import a export na stávající cílová zařízení (proprietární GPS moduly, GIS programy). Jasně a zřetelně se hlásí k svobodným licencím a využívá jiné legální zdroje dat. Části datového modelu jsou otevřené uživatelům, kteří jej upravují dle jejich potřeb a možností. Projekt není určen jen pro vybraný region, národnost; vytvářet data lze pro celém světě a v libovolném jazyce.

Cílem projektu je vytvářet otevřená polohopisná geografická data s širokým okruhem obslužných aplikací na principech komunitní otevřené a sdílené práce.

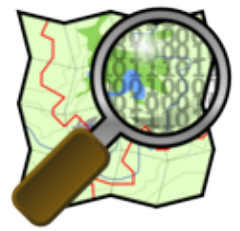

Figure 1: Logo projektu OpenStreetMap

\section{Historie OpenStreetMap}

Projekt OSM vzniká v červenci roku 2004 v Anglii, kde je registrována doména OSM ${ }^{12}$, stojí za ním Stephen Coast, Richard Fairhurst. Výrazné osoby se přidávají z Německa Immanuel Scholz, Frederik Ramm, Jochen Topf a další...

- V začátkem roku 2006 začínají vznikat národní sekce, obvykle na na úrovni států, které spolupracují při tvorbě dat v daném regionu.

- V dubnu 2006 vzniká nadace OpenStreetMap, která má za úkol shromažd'ovat finanční prostředky na podporu projektu OSM.

- V ř́jnu 2006 se přidávají první uživatelé z Česka a vznikají zde první data.

\footnotetext{
${ }^{11}$ http://grass.fsv.cvut.cz/wiki/index.php/FreeGeodataCZ

${ }^{12}$ http://www .openstreetmap.org/
} 
- V prosinci 2006 je pro OSM významné uvolnění družicových snímků Ikonos prostřednictvím serveru maps.yahoo.com ${ }^{13}$ pro legální tvorbu dat.

- V listopadu 2007 je v OSM ČR plně dostupná silniční sít I. a II. tříd a dálnic

\section{Licence}

V rámci projektu OSM je zvykem využívat licence GNU GPL pro podpůrný software. Často se jedná o Java, Perl, C, Python, Ruby aplikace využívající jiné knihovny svobodného softwaru. Tato licence je i v Česku podle rozborů některých právníků pod právní ochranou [4],[5],[6].

Pro geodata je užívána licence Creative Common Attribution-ShareAlike 2.0 ${ }^{14}$ (zkráceně CC BY-SA 2.0), někteří uživatelé je navíc poskytují pod licencí Public Domain. Licence $C C B Y$ $S A 2.0$ umožňuje data volně kopírovat, měnit i prodávat za předpokladu, že jejich libovolná modifikace nebo interpretace bude opět dostupná pod touto licencí.

Ve Francii dříve formulovaná licence Public Geodata License ${ }^{15}$ (český překlad ${ }^{16}$ PGL), nebyla nakonec komunitou použita.

\section{Referenční rámec a model geodat}

\section{Polohopisná složka}

Projekt OSM se zabývá sběrem polohopisných dat, pro něž je využíváno geodetické datum WGS-84, jak je definováno v EPSG:4326.

\section{Výškopis}

Výškopis není předmětem sběru dat. Pro účely překrývajících se objektů (nejčastěji mosty, tunely, plochy zeleně a vody) lze využít tématický klíc, kterým lze definovat pořadí zobrazení jednotlivých prvků.

Uvažuje-li se o využití výškopisných dat jako doplňující informaci k polohopisu v podobě reliéfu nebo vrstevnic, pak jako zdroj je nejčastěji užíván SRTM3, nebo GTOPO30.

\section{Tématická složka}

Tématická složka je robustní a nejvíce dynamickou složkou komunitního wiki [7]. Uživatelé navrhují a schvalují rozličné vlastnosti, které mají potřebu mapovat, nebo je považují za důležité. V současné době obsahují sady značek (tagů) pro fyzické objekty[17]:

- dopravní komunikace a zařízení (silniční, železniční, vodní a letecká doprava)

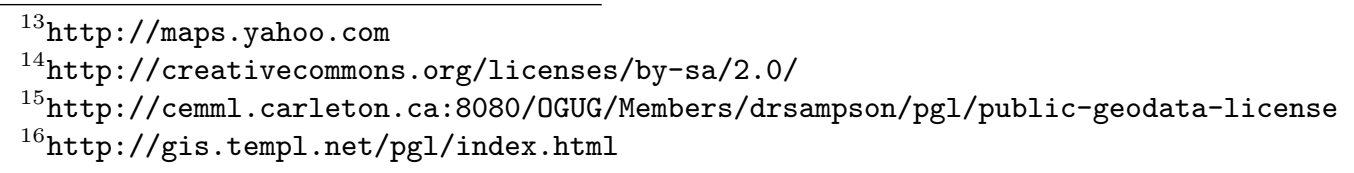


- občanské, průmyslové a vojenské objekty a areály

- využití kulturní, urbanistické krajiny nebo krajinný pokryv, vodstvo

- občanská vybavenost

- turistické a historické objekty

a abstraktní, rozšiřující, doplňující nebo omezující sady značek (tagů):

- trasy (hromadná doprava, cyklokoridory)

- administrativní hranice

- volnočasové aktivity

- okolí objekti̊

- příslušenství a obecné vlastnosti

- omezení (především dopravní)

- názvy

- místopis

- poznámkový aparát

\section{Datová primitiva}

Centrální databáze [8] shromažd’uje uživateli vytvářená geodata, která jsou tvořena dvěma základními prvky, které nesou unikátní index, časové razítko, autora a informaci o své existenci (platnosti). Jsou to:

- nodes (uzly) - jako jediné nesou samy o sobě přímou polohovou informaci.

- ways (cesty) - jsou uspořádané orientované posloupnosti nodů, kde se každý uzel vyskytuje nejvýše jednou.

- areas (plochy) - v případě že cesta je uzavřená (první a poslední uzel je totožný), považuje se za plochu.

\section{Rozšiřující prvky}

- tags (značky) - je výčet možných proměnných a jejich hodnot pro popisnou složku geodat

- relations (vztahy) - vztahy je náznak budoucnosti v rozšířených možnostech seskupování a určování rolí primitiv pro zjednodušení správy editace a udržování objektů.

Vývoj struktury datových primitiv je ve zkratce následující: [9]

1. nodes, segments (orientované hrany) + tags

2. nodes, segments (orientované hrany), ways(posloupnost hran) + tags

3. současný stav: nodes, ways + tags, relations 
4. budoucnost?: nodes, ways + tags, s plným uplatněním relations, historie změn a metaeditační data [12][13]

Jejich schématické zobrazení je na obrázku [Figure 2], strukturu zápisu do souboru na schématu [Figure 3].
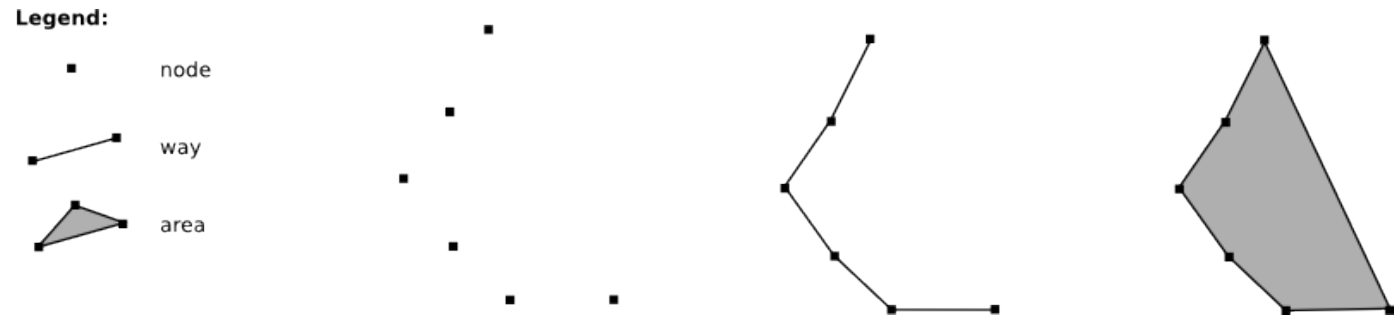

Figure 2: Primitiva modelu OSM: node, way, area

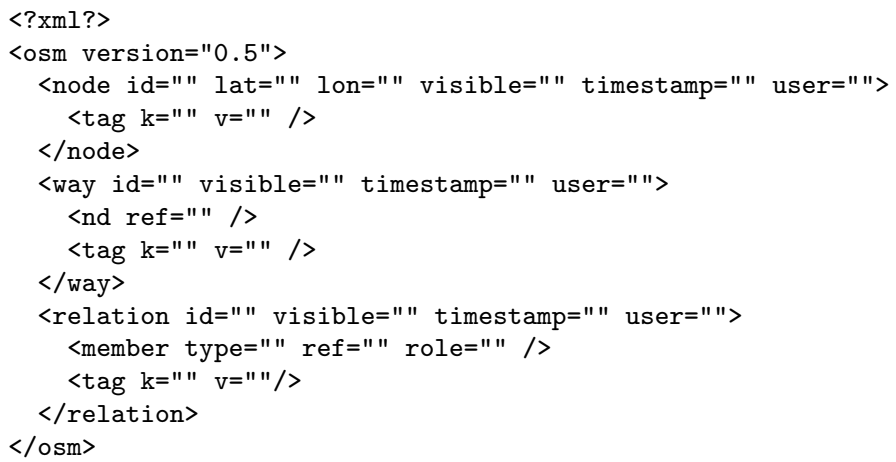

Figure 3. Vzorový XML zápis OSM modelu

Centrální databáze OSM skrze API poskytuje uživatelům poslední aktuální data z požadované geografické oblasti a jejich opravy přijímá pouze inkrementálně. Veškerá historie zůstává tedy archivována, její využití není zatím do žádného uživatelského editoru plně implementováno, částečnou lze najít v online editoru Potlatch. Jako demonstraci možností historie je webová aplikace OSM History ${ }^{17}$ vytvářející animovaný rastrový obrázek s růstem dat vybrané oblasti $\mathrm{v}$ čase.

\section{Záznamy z GPS přijímačů}

Databáze má také vyhrazenou část pro sběr samotných záznamů z GPS přijímačů (tracklog) ve formátu GPX. Zdrojová data tak nezůstávají skryta u původních uživatelů, ale mohou být použita jako podklad pro nová geodata odvozená jiným způsobem, nebo v jiném čase.

\section{Zdroje dat}

Zdrojem dat pro projekt OSM jsou především individuální záznamy (tracklogy) uživatelů z přijímačů GPS. Jejich postupný růst doplňuje několik licenčně kompatibilních datasetů s rozsáhlým pokrytím:

\footnotetext{
${ }^{17}$ http://openstreetmap.gryph.de/history/
} 
1. vektorová mapa $\operatorname{Vmap0}$ (autor NIMA) - celý svět 1:1 000000

2. družicové snímky Landsat 7 pořízené v roce 1999-2001 (autor NASA) - rozlišení 30m

3. družicové snímky hlavních měst států (poskytovatel Yahoo) - v Česku pouze Praha a okolí (rozlišení 2m, snímky družice Ikonos z roku 2002)

4. letecké snímky území ČR z let 1998-2001 jejichž původcem je ČÚZK, poskytovatel skrze WMS a licence pro OSM je ÚHUL.

5. mapy bez autorských práv - volná licence

6. mapy, kde vypršela autorská práva - v Česku 70 let od smrti (posledního) autora

Lokální datasety jako např. TIGER v USA nebo $A N D$ v Holandsku nejsou ve výčtu uvedeny a starají se o ně obvykle národní mapovací skupiny OSM.

\section{Součásti projektu}

Projekt OSM se skládá z několika fyzicky nebo logicky dílčích částí [10]:

- www (Amsterdam, NL) - mapserver, který zpřístupňuje databanku rastrových výřezů

- tile (Londýn, UK) - databanka výřezů map v rastrovém formátu

- tilegen - rendrovací server, který z planet.osm vytváří rastrové výřezy map

- planet (Londýn, UK) - týdenní export aktuální verze geodat z databáze do jednoho XML souboru, jeho velikost je po kompresi bz2 ve stovkách MB (300 MB v červenci 2007)

- api (Londýn, UK) - API k databázi geodat

- db (Londýn, UK) - databáze geodat, provozovaná v MySQL, která poskytuje data k editaci a přijímá modifikovaná nebo nová data, udržuje historii dat

- wiki (York, UK) - wiki rozhraní pro dlouhodobou výměnu informací uvnitř projektu, spravovaná všemi uživateli

- svn (York, UK) - subversion rozhraní pro vývoj aplikací a skriptů

- $\operatorname{dev}($ Amsterdam, NL) - testovací rozhraní vývojářů, některý vývoj a testování probíhá na soukromých strojích, jako např. editor JOSM v Německu.

- mail (York, UK) - rozhraní pro e-mailové konference talk, talk-dev, talk-*

- blog (York, UK) - blog stručných zpráv z konferencí a událostí okolo OSM

\section{Software}

\section{API}




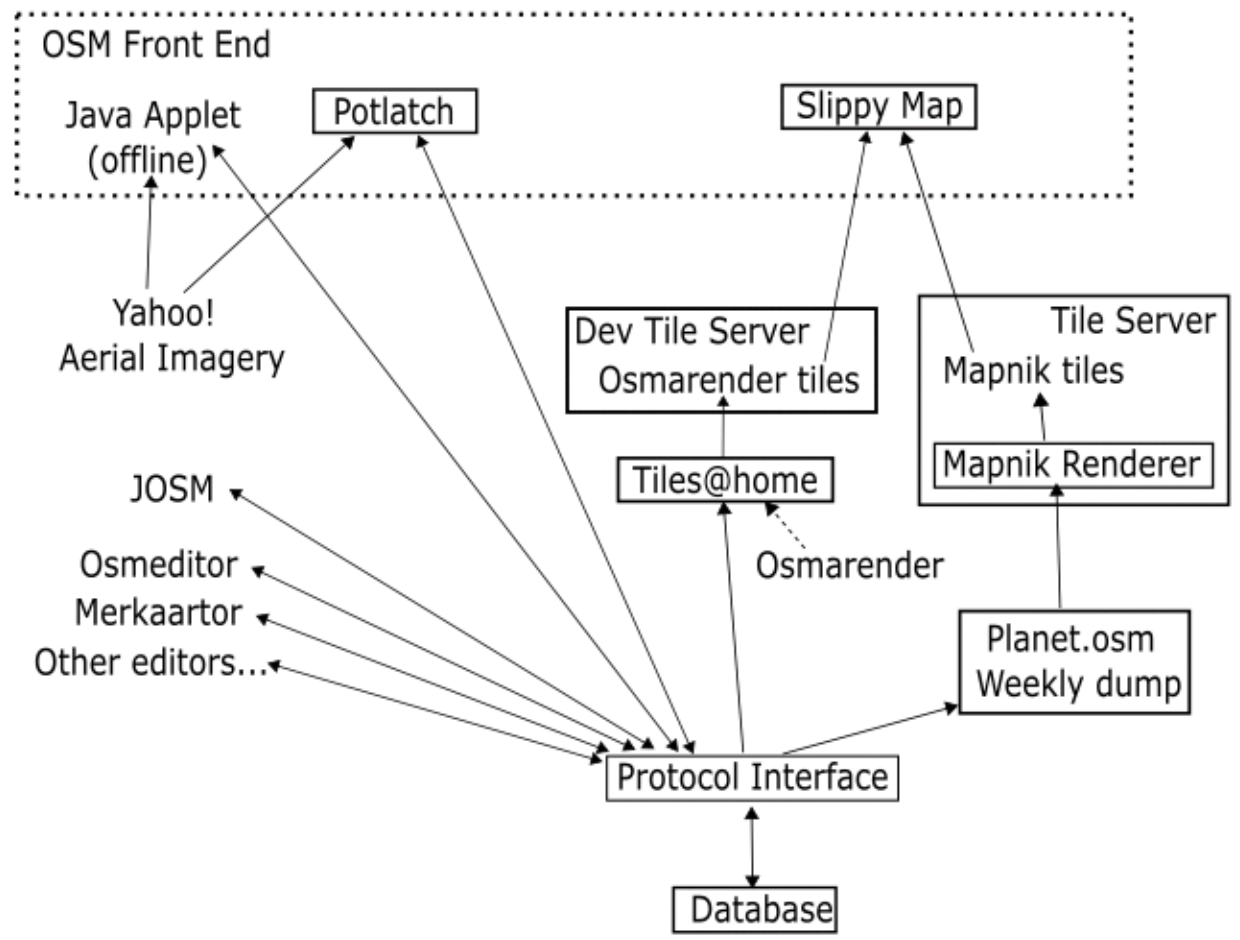

Figure 4: Diagram komponent OSM. Převzato z [10].

API [11] je klíčovou částí OSM nebot’ propojuje vnější svět s databází geodat. Maximálně využívá existujících standardů a jen to nezbytné přidává. Základem je sítová vrstva IP, transportní vrstva TCP a aplikační vrstva HTTP. Poslední a jediná podporovaná verze API je 0.5. Základní požadavek klienta je pro HTTP specifikován:

"http:" "//" host [ ":" port ] [ abs_path ["?" query ]]

Dotaz na jeden konkrétní prvek node, např.:

http://api.openstreetmap.org/api/0.5/node/35

\section{Uživatelské editory dat}

Jedná se o programy, kterými uživatelé přistupují k datovému skladu ze svých domácích počítačů a s nimiž upravují geodata OSM. Úpravy je možno provádět jen z dat umístěných v centrálnímu datovému skladu a to při připojení:

1. dočasném (např. JOSM) - uživatel si nejprve stáhne soubor dat, provede úpravy, zkontroluje konflikty a odešle data zpět do datového skladu.

2. stálém (např. Potlach) - uživatel si na mapserveru nalezne oblast k editaci, na požadavek je mu umožněn přístup $\mathrm{k}$ vektorové podobě a provedené změny lze průběžně odesílat, př́ipadně vracet (i za hranici editací aktuálního uživatele).

Mezi editory patří: 
- JOSM (viz Figure 5) - "Java OSM" je plně funkční a použitelný editor OSM dat. Původním autorem je Immanuel Scholz. Program vlastní nástroje na vytváření, editaci a modifikaci dat, jejich značkování. Umí řešit editační konflikty aktuálních editací a zobrazuje autory jednotlivých prvků. Nyní je dostupný zkompilovaný ve stabilní verzi 1.5 a vývojové verzi. Umožňuje vytvořená data ukládat na disk, podkládat záznamy cest z GPS přijímačů (tracklogy) ve formátu GPX. Je rozšiřitelný pomocí pluginů, mezi nejzajímavější patří pokročilý $W M S$ klient (jehož implementace je umožňuje velmi efektivní práci s WMS v produktech GIS jako např. ArcGIS neznámou), Mappaint pro vylepšené zobrazování editovaných dat, Validator korektního značkování).

- Potlatch - Flash internetová aplikace pro on-line editaci dat, jejíž autorem je Richard Fairhurst. Aplikace je vyvíjena především pro licenční kompatibilitu s Yahoo Maps používaných jako podkladní vrstva pod vynášená geodata. Vyvíjena od ledna 2007.

- a jiné jako Osmeditor, Merkaator, Osmpedit, Java on-line applet - jejich vývoj byl z různých důvodů ukončen nebo jejich vývojáři nedrží bezprostřední krok s vývojem projektu OSM a často jejich poslední vydání není kompatibilní s aktuálním API.

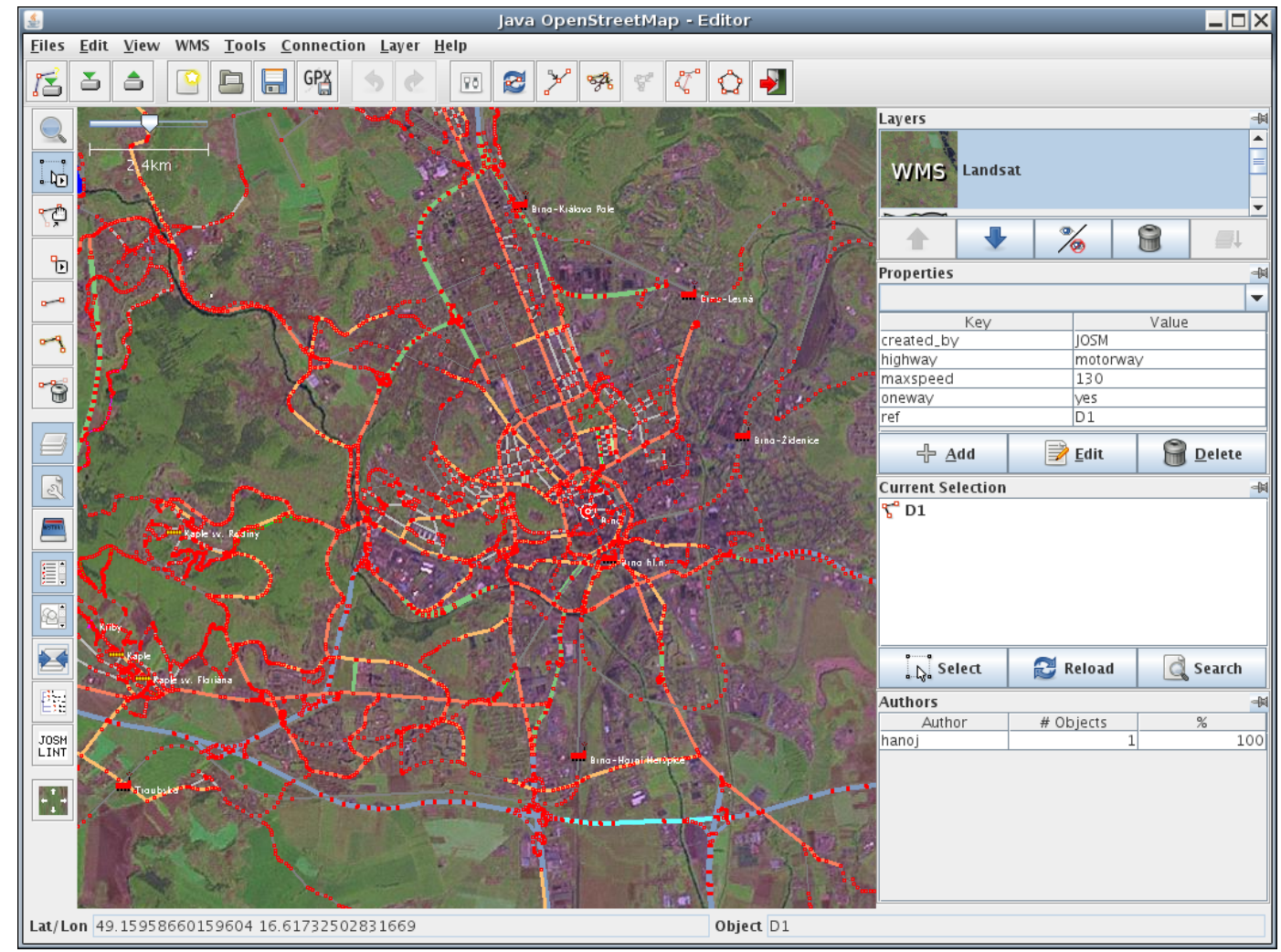

Figure 5: Java editor JOSM 1.5 (WMS a mappaint plugin) s daty z Brna 9. 6. 2007, podloženým snímky z Landsatu. Provozováno na GNU/Linux Ubuntu 7.04 a SUN Java 1.6.

\section{Renderery}

Programy, které transformují data ze souboru XML formátu OSM na vektorové obrázky XML formátu SVG nebo rastrové obrázky PNG. 
- Mapnik (viz Figure 6) - program napsaný v C++, rozhraní v Pythonu a propojený s jinými knihovnami, určený především pro běh na serveru. Předpokládá import Planet.osm do PostgreSql databáze. Po definování výřezu v zeměpisné širrce a délce vytvoří databanku obrázků použitelných především pro mapserver. Výsledek aktualizovaný přibližně jednou týdně je dostupný jako implicitní zdroj dat na oficiálním mapserveru.

- Osmarender (viz Figure 7) - individuální renderer aktuální verze 6. Využívá transformačních stylů XSL a skrze XML parser vytváŕí vektorové obrázky map ve formátu SVG. Je určen pro koncové uživatele (dostupný i jako plugin pro JOSM).

- tiles@home - rozššřená a upravená verze Osmarenderu o schopnost distribuovatelných výpočtů podle vzoru seti@home. Uživatel si bud' vybere oblast, kterou chce udržovat aktuální, nebo převezme od serveru požadavek, který je na základě žádosti uživatelů nebo změny dat v databázi. Klient si stáhne aktuální data, vytvoří výstup obrázků pro databanku a zašle jej zpět. Výsledek, průběžně aktualizovaný, je dostupný jako volitelný zdroj dat na oficiálním mapserveru.

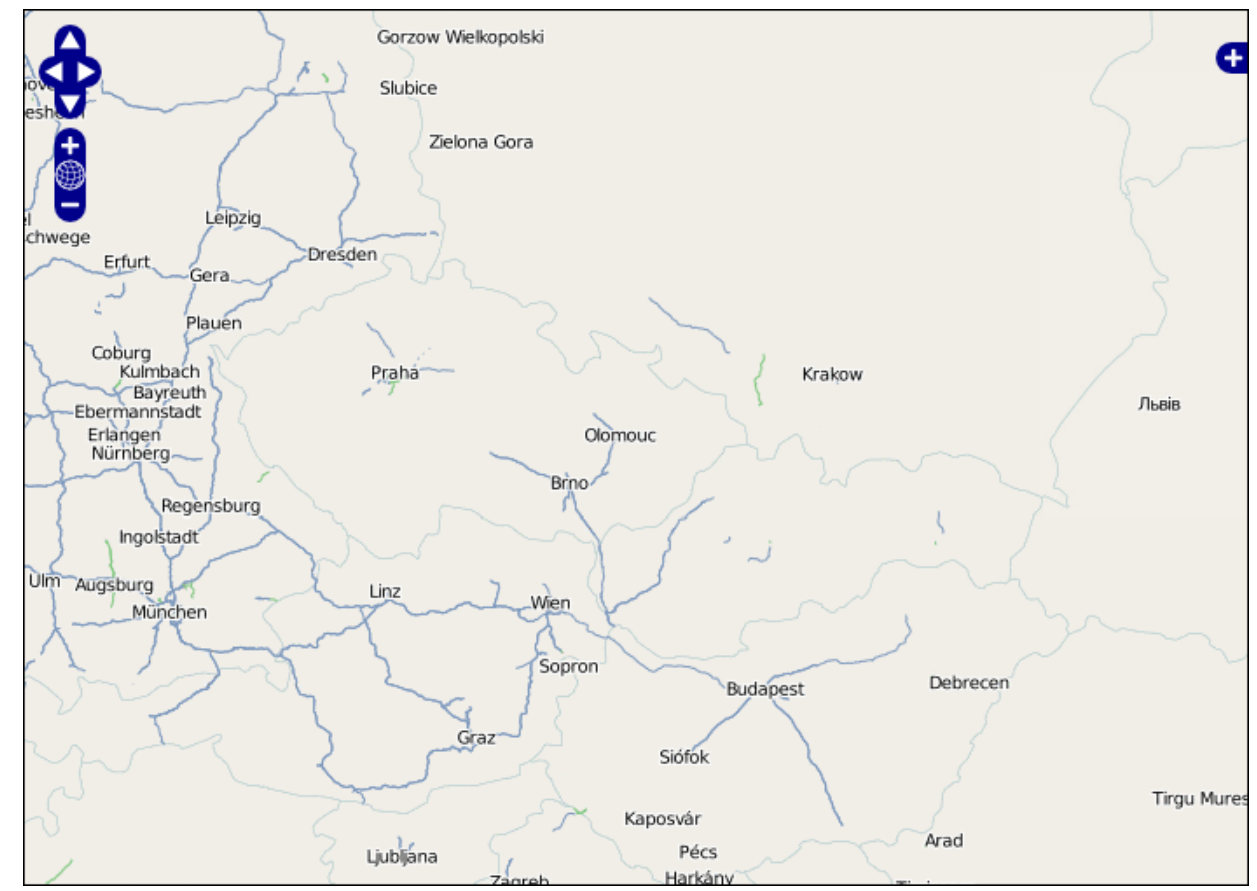

Figure 6: Ukázka zobrazených dat ve webovém prohlížeči. Dálnice a rychlostní silnice Česka a jeho sousedu z renderu Mapnik dostupného na mapserveru www.openstreetmap.org ze dne 2. 4. 2007.

\section{Fenomén OSM}

\section{OpenAerialMap}

Postupně jak se projekt OSM rozšiřuje mezi uživatele vznikají sesterské projekty, které přímo s OSM nesouvisí, ale poskytují mu podporu, nebo rozšiřují jeho možnosti. Jedním z takových 


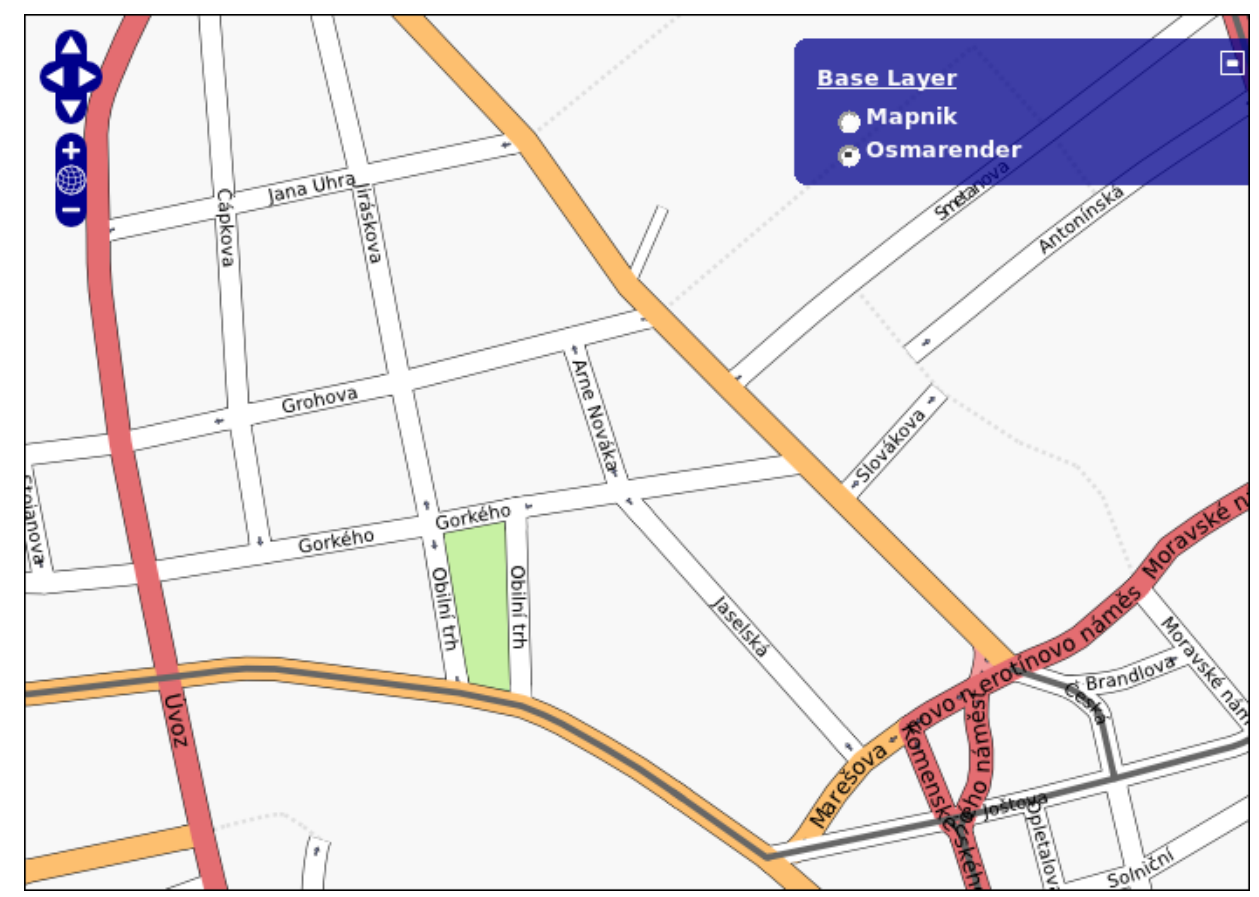

Figure 7: Ukázka zobrazených dat ve webovém prohlížeči. Oblast centra města Brna (pouze nekompletní silniční sít) z renderu Osmarender verze 4 dostupného na mapserveru www.openstreetmap.org ze dne 2. 4. 2007.

projekti̊ je OpenAerialMap www.openaerialmap.org, který si klade za cíl agregovat známé snímky DPZ ve viditelném spektru pod volnou licencí. Základem je snímek z Landsat 7, který je v malých měřítkách překryt podrobnějšími snímky. Server komunikuje především WMS rozhraním a jako mapserver, který na požadavky uživatelů poskytuje lokální kopie, nebo je přeposílá na původní servery správců dat. Pokud to licence dovoluje, jsou ukládány do vyrovnávací paměti. Další možností je vložit přímo nasnímané a rektifikované snímky. Někteří uživatelé jdou až tak daleko, že kombinací bezpilotních leteckých prostředků, GPS přijímačů a fotoaparátů, produkují svá původní data DPZ.

\section{The State of the Map}

Mnoho uživatelů OSM vystupuje se svými prríspěvky o projektu na rozličných konferencích. Uvnitř komunity však vznikla potřeba potřeba zpětné vazby projektu a osobního kontaktu. Proto byla 14.-15. července 2007 na univerzitě v Manchesteru (UK) uspořádána konference The State of the Map ${ }^{18}$ o teoretických základech, stavu a vývoji OSM či sesterských nebo jiných inspirativních geoinformačních projektech. Další ročník konference byl v Limericku (Irsko) 12.-13. července 2008. Třetí roční bude 10.-12. července 2009 v holandském Amsterodamu.

\section{The State of the Map}

Figure 8: Logo konference The State of the Map

\footnotetext{
${ }^{18}$ http://www. stateof themap.org/
} 


\section{Místní setkání}

V zemích západní Evropy, kde se také nachází větší počet uživatelů, se pořádají školící akce pro nové uživatele, neformální setkání a mapovací akce. Úkolem akcí je systematicky pokrýt daty dosud plně nezaznamenanou část urbanizovaného území, nebo domapovat odlehlé části měst.

\section{Nadace OSM}

V Anglii vznikla i nadace nezávislá na projektu, která si klade za cíl získávat peníze na podporu, propagaci projektu OSM. Jedná se o právnický subjekt, který reprezentují osoby podílející se na vývoji projektu, kteří nesou tíhu vývoje. Finanční prostředky jsou určeny pro vývoj, provozu a udržování hardware projektu.

\section{Vlastnosti komunitního projektu}

Komunitní projekty mají své specifické vlastnosti, které vyplývají z charakteru uživatelů a jejich organizace. Při takových úvahách nám může pomoci příklad Wikipedie, která má delší historii a popularitu a přes jiné zaměření obdobné problémy.

\section{Pohled geoinformatika}

Pro základní hodnocení projektů obvykle uvažujeme měřítka např. finanční a časové efektivity, nebo účelnosti. V OSM není možno finančního měřítka pro dobrovolnost využít, čas dosažení i obecného cíle je velmi subjektivně chápán každým uživatelem.

Jako jeden z cílů můžeme definovat vytváření polohopisných map velkých měřítek s možností generalizace pro střední a malá měřítka s obsahovou náplní automap, plánů měst, cyklomap. Další z cílů je routovací mapa pro navigaci. Architektura systému tyto dva cíle umožňuje a jejich naplnění je jen otázkou počtu dobrovolníků a definování požadované úrovně kvality a především obsahové náležitosti. Také hardwarové řešení je pro tisíce dlouhodobě aktivních uživatelů udržitelné v provozu.

Vývoj datového modelu ukazuje jeho živelný růst spolu s touhou uživatelů pracovat. Snaha začít projekt zcela od počátku bez robustního a odzkoušeného datového modelu způsobuje ještě nyní komplikace. Jedná se především o konvertibilnost formátu OSM do GIS standardních formátů a následné možnosti využití nástrojů geoinformačních technologií (např. GDAL). Další historickou tíží datového modelu je nevhodnost snadné a dlouhodobé údržby dat, nebot dosavadní implementace modelu v editorech vyžaduje přístup k datům na nízké úrovni, tedy i dostatečné znalosti a zručnosti uživatelů. Původní jednoduchost datového modelu umožňovala snadný vývoj obslužných aplikací, nyní však v přechodném stádiu od jednoduchého k pokročilé struktuře modelu je jak správa geoprvků tak obslužných aplikací netriviální.

Z pohledu operátora GIS má projekt využití jako doplňkového zdroje dat, případně základní orientace, nejsou-li v daném okamžiku dostupná jiná data (např. ověření informace o elementární korektnosti georeferencování třetí stranou). Nyní je v OSM třeba uvažovat: 
- kvalita polohového měření ani obsahové náplně není definována.

- metadata o mapovaných objektech, prováděných změnách, zdrojí informací nejsou jednotná ani obecně používaná.

- konvence práce při vytváření jsou definovány pouze v obecné rovině.

- pokrytí daty, rozsah zmapovaných území není možno specifikovat a nesnadná je i statistická konfrontace úplnosti (např. silnice v OSM versus Jednotná dopravní vektorová mapa)

- konvertibilnost dat je netriviální, komplikovaný systém rolí není dostatečně triviální pro vytvoření dlouhodobého a univerzálního exportu do jiných formátů.

- geodetické základy využívá parametry WGS-84, tedy po úspěšné konverzi formátu je už plná kompatibilta se standardy

- znalost místního významu obsažená v mapě může být cennou informací; v optimálním př́ípadě může být aktuální (změny v klasických mapách trvají dlouho a stojí nové peníze) a vyjadřující skutečné využití (nejen prvotní či pưvodní účel)

\section{Projekt}

Projekt OSM je jako organismus, neexistuje žádná finální nebo stabilní verze. Stále se rozšiřuje co do kvality obsahu, tak do kvantity mapovaného území. Mnoho částí projektu je v základním a neustálém vývoji, jsou sice použitelné a zprovoznitelné, ale vyžadují však značnou zručnost a zkušenosti. V souvislosti s neustálým růstem a změnami neexistují často manuály skriptů či programů. Časté změny pravidel pro editaci a zadávání dat ponechávají mnohé návazné části projektů ve zpoždění a tak např. některé značky (tagy) není možno v globálním mapserveru renderovat.

Velká variabilita systému je ovlivňovaná poptávkou uživatelů a konkrétním zájmem mapovat. To dává za následek malou jednotnost a koncepčnost značkování geoprvkủ. Problémem každého začínajícího projektu je řídké pokrytí daty, jehož růst se s časem zpomaluje, případně se zaciluje jen na urbanizovaná nebo navštěvovaná místa. Každý uživatel pracující jen s výstupy svého GPS přijímače je přibližně do roka informačně vytěžen, pokud se nestává OSM jeho hlavní koníček a cestování cíleně vyhledává. V létě 2007 působí na území ČR asi 10 uživatelů/editorů dat, na jaře 2008 už asi 20, z čehož polovina má spojitost s Prahou, další jsou rozeseti po městech a městysech. Pro základní a postupné mapování míst "Hic sunt leones" by bylo zapotřebí mnohem více uživatelů.

Velkou otázkou také zůstává aktualizovatelnost dat, či samoopravný mechanismus chyb na straně uživatelů. Problémem jsou i změny mapovaných objektů a verifikace dat bez většího počtu zodpovědných uživatelů, kteří by měli pod svým dohledem především data z území, kde se každodenně pohybují a kde jsou sami znalci místního významu.

\section{Uživatelé}

Hlavním motorem projektu je Evropa a konkrétně Angličané a Němci, nebot’ zde má projekt největší počet aktivních uživatelů a vývojářů, vysoké pokrytí území daty. Ti udávají základní 
tón projektu a mají také velkou členskou základnu. Komunikace je mimo národní celky vždy $\mathrm{v}$ angličtině.

Většina uživatelů pochází profesně mimo obory geovědní, často se jedná o studenty se zjevným zájmem v informatice. Proto se potřebují naučit elementární návyky ve vizuální interpretaci, dále syntaxi, sémantiku, systematiku a topologii. I pokud odhlédneme od různé vyzrálosti uživatelů a budeme předpokládat, že mají znalosti stejné úrovně a aktuální, přesto produkují různou kvalitu dat různými metodami sběru, editace a osobních zvyklostí a každodenní náplní.

Uživatelé mají také o projektu rozličné představy z jejichž premis přistupují k projektu:

- Až jednou charakterizuje uživatele, který vkládání dat vnímá jako dlouhodobý maraton

- Ihned je charakter uživatele, který vnímá zadání a využití dat aktuálně v přítomném čase

- Kvalita je vlastnost, která určuje, že uživatel vnímá vysokou hodnotu dat (přesnost, pravdivost, ověrenost), jako klíčové parametry

- Cokoliv je vlastnost, která určuje, že uživatel vkládá cokoliv a hledí předeším na vysokou penetraci dat

Všichni uživatelé jsou si rovni a neexistují žádné formální třídy (správci), které by řešily spory, garantovaly editace a zásahy. Určitá privilegia mají hlavní vývojáři, velká míra demokracie je př̀i schvalování nových značek. Pro př́liš velká bílá místa se uživatelé prozatím potkávají zřídka a spory jsou zatím jen drobné na mezinárodní úrovni, např. Řecko, blízkovýchodní oblast, kde občas prosakují vleklé politické problémy.

Zajímavým aspektem jsou záškodníci, kteří by chtěli projekt poškodit. Pokud by se na jejich činnost nepřišlo včas, bylo by (po jejich zablokování obtížné) jejich vandalismus obnovit do původního stavu, nebot' $\mathrm{k}$ historii v hlavní databázi OSM lze přistupovat pouze diskrétně a od přítomnosti do minulosti. Navíc pro práci s historií není vyvinut žádný uživatelský program, nebo sada skriptů.

\section{Závěr}

Projekt OpenStreetMap tu existuje několik let a žije svým vlastním životem mimo dosavadní struktury zajímající se o mapování povrchu především urbanizované země. Prodělává možná zbytečně dětské nemoci, je na počátku, nedaleko chvíle, kdy mapa byla zcela prázdná. Zaplnění bílých míst je možná na první, v ČR nepočetnou, generaci nadšenců př́liš velký úkol. Tedy ještě dlouho nebude jako jediný zdroj možné uvažovat o OSM. Nicméně OpenStreetMap je životaschopným zdrojem svobodných geodat. Veřejnost, která si ho pomalu bere za svůj, je jeho velký potenciál. Je jen na geoinformaticích, zda se budou chtít do něho zapojit a promítnout v něm své zkušenosti tak, aby jej mohly později využívat jako relevantní nebo paralelní zdroj geodat. 


\section{Reference}

1. Rapant Petr: Družicové polohové systémy. VŠB-TU Ostrava, 2002. 200 str. ISBN 80248-0124-8. [cit. 2008-03-30] Dostupný na WWW: online ${ }^{19}$

2. Free Software Foundation: The Free Software Definition online ${ }^{20}$. [cit. 2007-06-30].

3. Zeměměřický úřad (2007): Výňatek z ceníku výkonů a výrobků ZÚ [online]. [cit. 200706-30]. Dostupný na WWW: online ${ }^{21}$.

4. Aujezdský Josef (2005): GNU GPL a použití českého práva [online]. Root [cit. 2007-0630]. Dostupný na WWW: online ${ }^{22}$.

5. Otevřel Petr (2007): Rozsudek ohledně GNU/GPL - přituhuje? [online]. Právo v informačních technologiích [cit. 2007-06-30]. Dostupný na WWW: online ${ }^{23}$.

6. Čermák Jiří (2001): GNU/GPL - Právní rozbor licence [online]. Root [cit. 2007-06-30]. Dostupný na WWW: online ${ }^{24}$.

7. wiki OpenStreetMap (2007): Map Features [online]. [cit. 2007-06-30]. Dostupný na WWW: online ${ }^{25}$.

8. wiki OpenStreetMap (2007): Database schema [online]. [cit. 2007-06-30]. Dostupný na WWW: online ${ }^{26}$.

9. Coast Stephen (2007). This Mapping Stuff Could Really Take Off. In The State Of The Map 2007. Manchester : [s.n.], 2007. Dostupný na WWW: online ${ }^{27}$.

10. wiki OpenStreetMap (2007): Platform Status [online]. [cit. 2007-06-30]. Dostupný na WWW: online ${ }^{28}$.

11. wiki OpenStreetMap (2007): Protocol [online]. [cit. 2007-06-30]. Dostupný na WWW: online $^{29}$.

12. Ramm Frederik, Topf Jochen (2007): Towards a New Data Model for OSM [online]. [cit. 2008-03-30]. Dostupný na WWW: online ${ }^{30}$.

13. Schuyler Erle (2007): In response to "Towards a New Data Model for OSM" [online]. [cit. 2008-03-30]. Dostupný na WWW: online ${ }^{31}$.

\footnotetext{
${ }^{19}$ http://gis.vsb.cz/Publikace/Knizni_Publikace/DNS_GPS/DNS_GPS.pdf

${ }^{20}$ http://www.gnu.org/philosophy/free-sw.html

${ }^{21}$ http ://www. cuzk.cz/GenerujSoubor. ashx?NAZEV=30-ZU_CENIK

${ }^{22}$ http://www.root.cz/clanky/gnu-gpl-a-pouziti-ceskeho-prava/

${ }^{23}$ http://www.pravoit.cz/view.php?nazevclanku=rozsudek-ohledne-gnugpl-prituhuje\&cisloclan / $\mathrm{ku}=2007050004$

${ }^{24}$ http://www.root.cz/clanky/gnugpl-pravni-rozbor-licence/

${ }^{25}$ http://wiki.openstreetmap.org/index.php/Map_Features

${ }^{26}$ http://wiki.openstreetmap.org/index.php/Database_schema

${ }^{27}$ http://www.slideshare.net/chippy/this-mapping-thing-could-really-take-off/

${ }^{28}$ http://wiki.openstreetmap.org/index.php/Platform_Status

${ }^{29}$ http://wiki.openstreetmap.org/index.php/Protocol

${ }^{30}$ http://www.remote.org/frederik/tmp/towards-a-new-data-model-for-osm.pdf

${ }^{31}$ http://freemap.in/ sderle/osm-data-model.html
} 
14. OpenStreetMap, talk-cs: WikiProject Czechia/free map2osm ${ }^{32}$ seznam vybraných datasetů pro OSM-cs, [cit. 2008-06-30]

15. Martin Landa: odpověd' v konferencis ${ }^{33}$ in FreeGeoCZ 27. prosinec 2006. [cit. 2007-06-30]

\footnotetext{
${ }^{32}$ http://wiki.openstreetmap.org/index.php/WikiProject_Czechia/free_map2osm

${ }^{33}$ http://mailman.fsv.cvut.cz/pipermail/freegeocz/2006-December/000118.html
} 